\title{
Nuclear Proliferation Deterrence: Bullying vs Diplomacy
}

\author{
Chidiebere C. Ogbonna \\ Department of Development Studies, Kampala International University, Uganda \\ chidiebere.ogbonna@lavache.com
}

\begin{abstract}
The article examines the plausibility of using sanctions as an instrument that can deter nuclear proliferation. Sanctions have been a favored policy tool in the arsenal of the international community, when it comes to issues relating to deterring nuclear proliferation. The adoptions of sanctions as a policy instrument that can quench the nuclear ambition of states and/or regimes are based on two main assumptions. First, it is believed that they add cost to the regime aspiring to acquire nuclear weapons, by limiting the regime's access to finance and thus discourage it from furthering its nuclear ambition. Second, it is believed that the impact of sanctions on the welfare and well-being of the citizens of a targeted regime will prompt the citizens to rebel against the regime and perhaps force it to comply with the demands of the sanctions imposing party. This article however, took a dissimilar view and argues that sanctions as a single policy tool cannot check nuclear proliferation. At best they can be used to express discontent or signal displeasure to a regime with nuclear ambition. The article concludes that diplomacy devoid of rapacity is and will remain the plausible mechanism to deter nuclear proliferation.
\end{abstract}

Keyword: Deterrence, Diplomacy, Nuclear Proliferation, Policy Tool, Sanctions

\section{Introduction}

The treaty on the Non-Proliferation of Nuclear Weapons, commonly known as the Non-Proliferation Treaty (NPT), entered into force in 1970 (Sokolski, 2010: 26). Since then, economic sanctions have been favored by the international community as a tool that can deter nuclear proliferation. Consequently, economic sanctions have been deployed against countries aspiring to acquire nuclear weapons. According to the United States (U.S.) State Department, the reason for employing economic sanctions as a deterring measure to regimes/countries aspiring to develop nuclear weapon is mainly to weaken and/or cripple the targeted regime's economic capability and thus forestall its nuclear ambition. The logic here is that developing nuclear weapon requires huge amount of capital, therefore, economic sanctions can potentially yield positive results by substantially and/or effectively curtail the amount of capital available to the target regime, thereby making it difficult for the regime to continue with its nuclear program and/or policy. The above argument seems reasonable and forthright; however the use of economic sanctions as a mechanism to stop and/or deter a country from acquiring nuclear weapon have had varying degrees of impact depending on the underlying economic and political conditions in the target country.

The belief or argument favoring the use of sanctions is that a change in the nuclear ambition of a targeted regime would be beneficial to the international community in terms of maintaining international peace and security. In this regard, sanctions are perceived as a means to some good end, in that though they may be ruthless to the population of a targeted regime, they aim to force the offending regime to comply with acceptable standards of behavior that the sender of sanctions perceives to be useful. In light of the above, the article examines the use of sanctions, which is also considered as bullying in place of diplomacy for the purpose of deterring nuclear proliferation. In doing so, it reviews the NPT as well as examines selected cases of nuclear proliferation where economic coercion/bullying where employed as deterrence. It concludes that bullying/economic coercion is not a plausible approach towards nuclear deterrence; as well, it cannot serve as alternative to diplomacy. Accordingly, the study proffers new insight on how to overhaul nuclear diplomacy and how same could be used by the international community to address North Korea's nuclear ambition, which seems to be the greatest nuclear threat to our contemporary world. The study proposes a shift from the use of conventional state diplomats to the engagement of 'alternative or non-conventional diplomacy', one that will incorporate renowned scholars, peace practitioners, artists and sports legends in negotiating North Korea's nuclear ambition. For the sake of clarity, the word economic sanctions, economic coercion and economic bullying were used interchangeably in this article. 
The Nuclear Non-Proliferation Treaty (NPT): On 6 August 1945, during World War II, the United States deployed the world first atomic bomb over the Japanese cities of Hiroshima and Nagasaki. The bomb resulted in the death of approximately 170,000 people in both Hiroshima and Nagasaki (Lindee, 1994; Khan, 2012). Then in the 1960 's, there was a prediction by presidents, prime ministers, and arms-control analysts that about 25 to 30 countries would possess nuclear weapons by the end of 20th century (Kaplan, 2005). Consequent upon the prediction, the world was petrified by an impending devastation from nuclear weapon proliferation. Therefore, a strategy to impede a potential nuclear disaster was hatched and thus gave birth to the NPT. In 1968, the United Nations drafted the NPT and states were obliged to sign and be part of the treaty in order to promote peaceful nuclear use. Presently, the NPT has been ratified by 189 countries. Prior to the NPT, there were five nuclear weapon states: China, France, the United Kingdom, the United States, and the Union of Soviet Socialist Republics (Alonso, 2012: 424). It is believed that since the initial signing of the NPT, India, Israel, and Pakistan have developed nuclear weapons, while North Korea is believed to have developed a nuclear explosive capability (Joyner, 2011). Among these four countries that later developed nuclear weapons and/or capability, India, Israel, and Pakistan were not signatory to the NPT, while North Korea ratified the treaty but later withdrew from the agreement.

Overall, the NPT has three main clauses. First, states seeking to be part of the treaty would agree to promote and also make efforts towards non-proliferation. That is to say, nuclear weapon states would agree not to transfer nuclear weapon devices or technology to non-nuclear weapon states. Besides, nuclear weapon states have to consent not to assist, influence, encourage, coerce or induce a non-nuclear weapon states to acquire nuclear weapon. The second main clause has to do with disarmament. The treaty requires consenting states to disarm and liquidate existing nuclear weapons and make efforts towards discouraging nuclear arms race. This implies that countries that already possess nuclear weapon or nuclear capability are required to destroy or get rid of their weapons. In essence, the NPT forbids both nuclear weapon proliferation and nuclear weapon safeguard. The third main clause in the agreement is the permission given to states to explore nuclear technology solely for peaceful purposes. By implication, nuclear technology can be exchanged, transferred or even traded between states as long as it is indicated that the technology will be used in a peaceful manner. This clause seems to be the biggest challenge in interpreting as well as implementing the NPT. This is because countries with nuclear ambition often claim that they are doing so for peaceful purposes as permitted by the NPT.

Another challenge facing the NPT is the lack of interest by the initial five nuclear weapon states to adhere to the recommendation of the treaty, by relinquishing their nuclear weapons. One may argue that the apparent expression of interest by these countries to keep and/or safeguard their nuclear weapons has sparked the interest of other countries that aspire to acquire their own nuclear capability. For example, the government of India while challenging the NPT argues that: "it is unfair for already nuclear nations to impose limiting sanctions on nuclear weapon development while they observe no signs of disarmament and liquidation of nuclear stockpiles from the nuclear states" (Khan, 2012). Therefore, the lack of political will among the original nuclear weapon states to relinquish their weapons is a factor that may propel other states to pursue a nuclear program, with the intention to achieve balance of power.

\section{Methodology}

The study employed the content analysis research method. The reason for adopting this method is primarily because the study is a qualitative research that relied heavily on documentary evidence in data collection. Therefore, the content analysis approach and secondary sources of data became imperative.

Cases of nuclear deterrence using sanctions: In different occasions, economic sanctions have been imposed with the aim to halt nuclear proliferation. Cases abound where sanctions and threat of sanctions have been used particularly by the United States to forestall nuclear ambitions. Although it is difficult to analyze the impact and/or degree of contribution made by sanctions in each case, in terms of delaying a nuclear program or persuading a government to abandon its nuclear policy, however, Hufbauer, Schott, Elliott and Oegg (2007) argue that sanctions have been successfully used to curb nuclear proliferation, though not in all cases where they were employed. In view of the above, this section of the article examines selected cases of nuclear deterrence using sanctions. 
India: On gaining independence from Britain in 1948, India became a vocal voice against nuclear proliferation, despite not being a party to the Nuclear Non-Proliferation Treaty. The country challenged the use of nuclear weapons and made statements discouraging other states from engaging in a nuclear arms race. In 1948, the country's spiritual leader Mohandas Karamchand Gandhi denounced nuclear proliferation when he made the following statement: "I regard the employment of the atom bomb for the wholesale destruction of men, women and children as the most diabolical use of science" (Veeravalli, 2014: 95). Gandhi's statement was viewed as one of the harshest criticisms of nuclear technology in that time. However, in 1955, India started a nuclear program with the aim of providing cheap electricity to its growing population. The initial stage of the program was facilitated by the U.S. and Britain, until the 1960's when the country's nuclear ambition changed from a "peaceful" nuclear program to the production of nuclear bomb.

It was suggested that the change in India's nuclear ambition was influenced by a number of factors, but mainly because of the presumed threat from Pakistan and China. As of 1974, India managed to develop and successfully launched its first nuclear test (Charnysh, 2009: 2) and in 1983, it launched an Integrated Guided Missile Program (IGMP). Shortly after that and precisely in 1989, it successfully tested both short and medium range missiles. Consequently, the U.S. and fourteen other Western countries including Japan, Australia, Canada, Germany, Denmark, and Sweden deployed economic coercion (sanctions) against India for unlawful nuclear activities (Morrow and Carriere, 1999: 5). Western sanctions focused on cancellation of aid to India. Japan cancelled development aid to India valued at $\$ 30$ million as well as loans worth $\$ 1.2$ billion. Germany on her part, suspended bilateral aid negotiation with India and cancelled development aid worth $\$ 168$ million. Also Denmark cancelled its aid to India worth \$28 million while Sweden cancelled \$119 million worth of aid. Furthermore, Canada and Australia suspended their aid valued at \$9.8 million and \$2.6 million respectively (Morrow and Carriere, 1999: 5). In addition, the World Bank and G-8 countries joined the sanctions and revoke non-humanitarian lending agreement with India. Remarkably, India defied the odds of sanctions and went ahead to produce a nuclear weapon. In 2012, the Federation of American Scientists reported that India has developed between 80 and 100 nuclear warheads (Raj, 2015).

Pakistan: Pakistan's nuclear ambition started around 1952 and in 1955, the country participated in the U.S. Atoms for Peace program (Weiss, 2003: 34). Initially, it was believed that Pakistan was seeking civilian nuclear capabilities, prompting a nuclear cooperation agreement to be signed between Washington and Islamabad, under which the later was offered $\$ 350,000$ in aid to facilitate its supposedly peaceful nuclear program (Charnysh, 2009: 1). However in 1974, Pakistan's nuclear program veered from civilian purpose to military nuclear aspiration. Different reasons were identified for this change and among them are: First, it is believed that Pakistan was threatened by India's development and testing of nuclear bomb in 1974. Second, Pakistani leaders believes that having nuclear weapons will earn them the respect associated with being a member of the nuclear club. In late 1974, a CIA report indicated that Pakistan may be able to produce nuclear bomb within 10 years if nothing is done to sabotage Islamabad's nuclear program. Consequently, the U.S. Congress adopted economic bullying as a remedy to Pakistan's nuclear ambition. In doing so, Congress passed the Pressler Amendment, cancelling all U.S. foreign aid to Pakistan until a time when it had denounced its nuclear weapon program.

Apart from the U.S., the UN joined the sanctions against Pakistan and in 1979 it suspended its military and economic aid to Islamabad (Charnysh, 2009: 2). The international community had believed that suspending aid to Pakistan will increase financial cost to the regime and thus force it to discontinue with its nuclear ambition. This overtly lorded assumption did not yield the expected result; instead U.S. intelligent report in 1990 confirmed that Pakistan was actually making progress in developing nuclear bomb. Reacting to the report, Washington slammed Pakistan with sanctions and all economic and military aid from Washington to Islamabad was effectively cancelled. Despite array of sanctions being put in place against Pakistan, in May 1998 it conducted successfully nuclear tests and stamped its name on the list of nuclear weapon states. It is estimated that Pakistan has about 60 nuclear warheads (Norris and Kristensen, 2007: 71) and the country continues to expand its nuclear weapons arsenal.

Iran: In February 2003, the National Council of Resistance on Iran revealed that it has launched a nuclear program in a site near Natanz and Arak, claiming that it was using the technology for peaceful purposes. Consequently, the UN nuclear monitoring body, the International Atomic Energy Agency (IAEA), was 
mandated to inspect the facility and make recommendation based on the NPT agreement. In 2005, the IAEA inspector's reported that "it could not confirm that Iran was not pursuing undeclared nuclear activities" (Toumaj, 2015: 1). In effect, the report did not prove that Iran was pursuing a nuclear weapon neither did it disprove it. However, scholars such as Hufbauer, Schott, Elliott and Oegg (2007: 233), posits that Iran has reasons why the regime would want to aspire to acquire nuclear weapons. First, it is believed that Iran considers a nuclear armed Israel as a deadly threat to its existence. Second, Iranian leaders believe that acquiring nuclear weapon, will increase the country's influence in the region and position it as a very important player in international affairs. On 31 July 2006, the Security Council adopted Resolution 1696 mandating Iran to suspend all uranium enrichment programs by 31 August 2006 - a request that was rejected by Tehran. In light of Iran's defiance to UN directives, on 23 December 2006, Council adopted resolution 1737 and imposed economic sanctions against Iran. The sanctions contained in Resolution 1737 were in twofold. First, it prohibited the supply of sensitive nuclear materials and technology to Iran. Second, it froze the assets of individuals and entities that were believed to be facilitating Iran's uranium enrichment activities. Subsequently, the Security Council adopted Resolution 1747 on 24 March 2007, Resolution 1803 on 3 March 2008 and Resolution 1929 on 9 June 2010, with all of them imposing different categories of sanctions on different sectors of Iran's economy, including entities and individuals believed to be supporting Iran's nuclear program (Davenport, 2015).

However, prior to UN sanctions, the U.S. has imposed different sets of economic sanctions against Iran, which focused intently on compelling Tehran to abandon its nuclear program or even to limit the scope of its nuclear activities to a level that may be considered "peaceful" to the international community. On 8 April 1992, the U.S. Congress believing that Iran was aspiring to produce nuclear bomb adopted the Iran-Iraq Arms Non-proliferation Act (IIANA) and imposed sanctions against Tehran. IIANA seeks to sanction entities that provide support for Iran's nuclear technology or any form of assistance that will facilitate the country's nuclear ambition. Thereafter, the U.S. imposed numerous other sanctions against Tehran, mainly through Presidential Executive Order. In 1995, President Bill Clinton issued Executive Order 12957 and declared Iran an "extraordinary national security threat" and called for national emergency to deal with it (Kattan, 2013). Accordingly, the President of the United States is permitted at all times to regulate trade with countries considered as "extraordinary threat." Thereupon, the president issued Executive Order 12959 on 6 May 1995, placing a comprehensive ban on U.S. trade with, and investment in Iran, with exclusion of food and medicine. Several other sanctions by the President and Congress followed. For example, Congress passed Iran Foreign Oil Sanctions Act, Iran and Libya Sanctions Act (ILSA) and Iran Missile Proliferation Sanctions and imposed different degrees of economic restrictions on Iran, while the President issued Executive Order 1305, which prevents U.S. companies from exporting goods to a third country that will eventually re-export them to Iran. These are just a highlight of the many U.S. sanctions against Iran's nuclear program.

Besides the UN and the U.S., the EU also imposed sanctions against Iran for the same purpose of deterring it from acquiring nuclear weapon. In July 2010, the EU imposed economic sanctions against Iran's energy and financial sector, banning the import of crude oil and blacklisted most of Iranian banks (Tabrizi and Santini, 2012: 2). Thus, Iran became the first country the EU sanctioned on issue relating to nuclear proliferation. According to the EU, the objective of implementing punitive measures against Iran is to persuade Tehran to comply with its international obligations and to hinder its development of sensitive technologies that will facilitate its nuclear and missile programs (ibid). In 2011, the EU imposed another set of sanctions against a number of Iranian officials for their alleged involvement in human rights violation. Those listed were banned from entry into the EU territory while their assets within the EU were seized. Then in March 2012, the EU adopted a decision and banned provision of financial communication services to exchange data with the Central Bank of Iran and some other banks in the country (EU Council Decision 2012/152/CFSP). Acting on EU Council decision, the world's biggest electronic payment system, Society for Worldwide Interbank Financial Telecommunication (SWIFT) halted its services to Iranian banks (Norman, 2012). SWIFT's action against Iran yielded the most hurting impact on Iran's economy. Foreign transfers from and to Iran were effectively blocked. Payment for exports from Iran and imports to Iran became impossible, creating cash trap for the government. Then, in the later part of 2012, the EU adopted additional sanctions against Iran. This time the Union imposed a total ban on the importation of Iranian natural gas into the EU (Buonanno; Cuglesan and Henderson, 2015: 53), as well as a ban on the export of certain sensitive materials such as metal, shipbuilding technology and oil storage facilities to Iran. In essence, the EU sanctions against Iran 
compliments the U.S. unilateral and the UN comprehensive economic sanctions against the country, which aims at sabotaging Tehran's nuclear program by denying the economy access to foreign finances and support. Nevertheless, sanctions were unable to achieve its goal, as Iran's nuclear program progressed albeit pressure from sanctions until a diplomatic agreement was reached between Iran and the P5+1 (China, France, Russia, the United Kingdom, and the United States; plus Germany) to halt the former's nuclear activities. Apparently, diplomacy proved to be a better alternative to bullying in this very case.

North Korea: North Korea, a backslide member of the NPT started its nuclear technology around 1956, when the Soviets started training North Korean scientists on basic knowledge on how to initiate a nuclear program (Bolton, 2012). Then in 1962, North Korea established the Yongbyon Nuclear Scientific Research Center, marking the beginning of its nuclear program. Some observers argue that North Korea's nuclear ambition was propelled by the U.S. deployment of a nuclear armed Honest John missiles and $280 \mathrm{~mm}$ atomic cannons to South Korea in 1958. It is believed that Pyongyang assumed that Washington was arming its neighbor (South Korea) for an imminent confrontation against it. Thus, North Korean leaders were convinced that acquiring a nuclear weapon is the only option that will guarantee the country's existence and safety. The U.S. however, withdrew its nuclear weapons from South Korea in December 1991, but North Korea continued with its nuclear program, which indicates that Pyongyang's nuclear ambition was not precipitated by fear of U.S. nuclear arsenal housed in South Korea; instead it shows that Pyongyang has a grand plan to acquire nuclear weapons and be part of the nuclear club. In January 1994, the CIA reported that North Korea may have produced one or two nuclear weapons. Consequently, the UN resorted to use economic sanctions against North Korea but the resolution failed to pass due to China's objection to the proposed sanctions against Pyongyang. Then in 2002, the UN World Food Program, significantly reduced its food aid to North Korea which affected about 3 million people.

In 2003, North Korea withdrew its membership of the NPT and between July and October 2006; it carried out series of nuclear tests. Consequently, the Security Council unanimously adopted a resolution and imposed both diplomatic and economic sanctions against North Korea. In total, the UN has adopted 16 resolutions in relation to the North Korean missile and nuclear program. Out of the 16 resolutions, 7 imposed different types and degrees of sanctions on North Korea. Security Council Resolution 1695 of 15 July 2006 and Resolution 1718 of 14 October 2006 imposed economic sanctions against North Korea for conducting a ballistic missiles test. Also Council Resolution 2094 of 7 March 2013, imposed sanctions against Pyongyang after its 2013 nuclear test. Similarly, Resolution 2270 of 2 March 2016, imposed further sanctions on North Korea after it conducted a nuclear and missile test in September 2016 (Davenport, 2016). In addition, Resolution 2270 prohibited all weapons trade with North Korea and bans the import of luxury goods from the country. Resolution 2321 of 30 November 2016 was adopted to strengthen previous sanctions against North Korea after its 9 September 2016 nuclear test. On 3 June 2017, Council ones again unanimously passed Resolution 2356 with new sanctions against North Korea after the regime launched its ninth ballistic missile test of the year.

Besides the UN, the United States and the EU also imposed different categories and degrees of sanctions against North Korea in an attempt to coerce the later to forgo its nuclear program. EU sanctions against North Korea include ban on the export of aviation and rocket fuel to North Korea, ban on the trade in gold, precious metals and diamonds with the North Korean government; ban on the exports of luxury goods to North Korea; restrictions on financial support for trade with North Korea; restrictions on investment and financial activities by EU citizens and entities with North Korea and prohibition of certain North Korean individuals from entering the EU (Fifield, 2016). Similarly, U.S. sanctions, which were mainly through Presidential Executive Order include, Executive Order 13466 of 26 June 2008 that places restrictions with respect to North Korea and North Korean Nationals; Executive Order 13551 of 30 August 2010, freezing the property of certain persons with respect to North Korea. Executive Order 13570 of 18 April 2011, prohibiting certain transactions with respect to North Korea and Executive Order 13722 of 16 March 2016, blocking property of the government of North Korea and the Workers' Party of Korea, and prohibiting certain transactions with respect to North Korea (U.S. Department of Treasury, 2017). In essence, sanctions have been a popular policy towards North Korea's nuclear ambition. However, Pyongyang has managed to develop and launch costly nuclear and ballistic missile test, despite being under the most draconian and one of the most widelyendorsed sanctions under the sun for decades. 


\section{Analysis and Results}

Sanctions have always been available in the menu of the international community in almost all cases relating to deterring nuclear proliferation. As a result, the rational question to ask is: have sanctions been able and are they still capable of achieving their set goals, in-terms of persuading targeted regimes to forgo their nuclear ambition? The cases examined above show that the degree of successes in using sanctions as a mechanism to forestall nuclear proliferation is dicey. A major argument by proponents of sanctions is that they fail because their implementation is often inconsistent - that is to say that they are either not tough enough to produce desired result or they are often sabotaged. Whilst the argument is reasonable, the issue is that the inconsistencies in implementation are frequent and almost evident in every sanctions episode that has to do with deterring nuclear proliferation. This article therefore, suggests that sanctions and/or economic bullying is not a reliable policy tool that can curtail a regime's nuclear appetite. Clearly, sanctions failed to stop Pakistan, India, Iran and North Korea from aspiring or acquiring nuclear weapon. It thus, challenges the notion that sanctions as a single policy tool has the capacity to deter nuclear proliferation. In the case of Iran, numerous sanctions by the U.S., the EU and the UN could not roll back Iran's nuclear ambition. Evidently, years of economic bullying were unable to reverse Tehran's nuclear policy, which diplomacy was able to accomplish in a short period of time. The nuclear agreement between Iran and the P5+1 on 14 July 2015, serves as a strong evidence and indication that diplomacy is and will remain the practical and most reliable solution to nuclear proliferation. As noted by the EU Foreign Policy Chief, Federica Mogherini, Iran's nuclear agreement shows that "diplomacy, coordination and corporation can overcome decades of conflicts" (Aljazeera, 2015). While President Obama reacted to the nuclear agreement by saying that: "diplomacy has achieved what decades of animosity could not achieve." He added that the nuclear deal "shows that diplomacy can bring real and meaningful change" (Gordon and Sanger, 2015).

Apart from Iran, North Korea's nuclear program poses the greatest challenge to world peace and security. According to the U.S. Secretary of Defense James Mattis, North Korea is a "clear and present danger" (Burns, 2017). Pyongyang has carried out a number of missile tests this year putting the region on edge and leaving the international community dismayed. The question now is: what could save the world from a nuclear armed North Korea? Just like Iran, the international community should betray their ego and re-engage North Korea diplomatically. Although previous talks did not yield desired goal and presently it appears to be difficult to engage North Korea in a dialogue, however, a statement made by the country's former leader Kim Jong II in 2005, when he was quoted as saying that "the country (North Korea) will return to talks if the U.S. shows "trustworthy sincerity" (Winder, 2005: 2) indicates that diplomacy is still a viable option. It shows that there is hope for a peaceful negotiation should the parties prove to each other that negotiation will be devoid of rapacity. In light of the above, the rhetoric's by Washington (Trump's administration) of possible use of force against Pyongyang should be channeled towards alternative options, of which diplomatic engagement is the most expedient. The international community should tap into the gains of Iran's nuclear agreement and forge a negotiation team that will re-engage North Korea in a dialogue. In that case, re-engaging North Korea should not be an issue between an individual state and North Korea, let say between Washington and Pyongyang or between Beijing and Pyongyang; instead it should include a coalition of states, particularly states that share business and diplomatic ties with North Korea and those with prior experience in nuclear negotiation. A negotiation team that include the United States, the United Kingdom, Iran, China, Russia and any other country(s) could deal with Pyongyang and Kim Jong-un's obscene appetite to be part of the nuclear club. However, the international community should not rely solely on the use of conventional state diplomats, reason being that the position of state diplomats are often influenced by their national interest and state policies. Consequently, the suggested diplomatic engagement of North Korea should incorporate 'alternative or non-conventional' diplomats that will include selected statesmen, renowned, scholars, artists and sports legends. Doing so, will add a new twist to the diplomatic approach towards North Korea's nuclear program and it will potentially curtail Pyongyang's nuclear threat to world peace, instead of reeling out more sanctions.

Giving the fact that economic bullying have being in place for more than two decades without achieving set goal, it is therefore evidently inapposite to rely on sanctions, no-matter how cruel they are as a single measure that can reverse Pyongyang's nuclear ambition. On the other hand, the use of force will produce an unpredictable outcome; hence it is not a conceivable option. One of the assumptions when adopting economic 
sanctions is that the hardship arising from the measure will instigate citizens to revolt against their leaders and possibly persuade them to adhere to the demands of the party imposing sanctions. However, this is not always the case because regimes with nuclear ambition are often insensitive to the plight and suffering of their citizens. Also, they are hyper-sensitive to opposition and as such will do anytime to crush contrary opinion and popular opposition. This is not to deny the fact that sanctions can make some contribution in deterring nuclear ambition. For example, in the case of Iran, it is believed that sanctions played a role in forcing the country to the negotiation table. However, the cases reviewed above shows that sanctions are not a reliable policy tool that can achieve nuclear deterrence on its own. Sanctions may be used for the purpose of signaling displeasure to a country aspiring to acquire nuclear weapon; however diplomacy (selfless negotiation and dialogue) is and will remain the plausible policy tool when the ultimate goal is to forestall the nuclear ambition of a state.

\section{Conclusion and Recommendations}

The incessant use of sanctions for the purpose of deterring nuclear proliferation raises questions of how polities and international entities address various incompatibilities. Obviously, any attempt to get the world free from a potential nuclear danger should be welcomed at least in the interest of humanity. Nonetheless, the question is: have sanctions been able to achieve this goal? The current situation with Iran and North Korea proves that instead of achieving compliance to demands, sanctions are in fact instigating provocations and add to the tension in world affairs. Contrary to sanctions, diplomacy seems to be the solution to nuclear proliferation and global peace and security. Diplomacy in our case should mean an inclusive, committed and continuous dialogue, devoid of vested interest, where negotiators must understand the need to be fair and transparent, while being wholly committed to peace during the entire negotiation process.

Suggestions: Based on the conclusions of this study, it puts forward the following recommendations:

- The international community should overhaul its nuclear diplomacy and strategy to include nonstate actors, such as representatives of major civil society groups, renowned scholars, artists and sports legends. In the case of North Korea's nuclear program, it is evident that there is lack of trust among state parties, therefore, the involvement of non-state actors/diplomats will renew trust and confidence among negotiators as well, it will foster neutral opinion and inputs to the negotiation and dialogue process. Most importantly, it will eliminate the issue of preconditions for negotiation, which has become one of the biggest challenges to world diplomacy.

- Although North Korean has constantly defiled orders by the international community instructing it to freeze its nuclear program, the fact remain that North Korean nuclear ambition could be propelled by the U.S. activities and unwarranted military presence in the Korean Peninsula. First, the U.S. holds a "pre-emptive first strike" policy toward North Korea, and has stationed an armed drone on the Korean Peninsula, which threatens Pyongyang. Second, the U.S. has more than 80 military bases in South Korea and every year in March and August, it conducts a joint war game with South Korea that includes dropping mock nuclear bombs on North Korea, thus frightening North Korea and escalating the tension in region. Therefore, to restore confidence and convince North Korean leader Kim Jongun that what happened to Muammar Gaddafi and Saddam Hussein will not repeat itself should he forgo his nuclear program, the U.S. must work to deescalate the tension in the Korean Peninsula by reducing its military presence and activities in the region. Washington should consider a freeze for a freeze proposal made by China, where North Korea will freeze its missile and nuclear tests in exchange for a halt on U.S.-South Korean war games. A consideration of the aforesaid will proffer an enabling environment for in-depth dialogue and the disarmament of North Korea. 


\section{References}

Aljazeera (2015). Iran and World Powers Clinch Historic Nuclear Deal, July 14. http://www.aljazeera.com/news/2015/07/iran-world-powers-clinch-historic-nuclear-deal150714042342330.html (March 28, 2017).

Alonso, A. (2012). Infrastructure and Methodologies for the Justification of Nuclear Power Programs, Cambridge: Woodhead Publishing.

Bolton, D. (2012). North Korea's Nuclear Program, American Security Project. www.americansecurityproject.org (March 14, 2017).

Buonanno, L., Cuglesan, F. \& Henderson, U. (2015). The New and Changing Transatlanticism: Politics and Policy Perspectives, New York: Routledge.

Burns, R. (2017). James Mattis Calls North Korea a 'Clear and Present Danger.' Time, Jun 03. http://time.com/4804124/james-mattis-north-korea-china/ (April 16, 2017).

Charnysh, V. (2009). Pakistan's Nuclear Program, Nuclear Age Peace Foundation. http://charnysh.net/Documents/charnysh_pakistan_analysis.pdf (May 04, 2017).

Davenport, K. (2015). UN Security Council Resolutions on Iran, Fact Sheets and Briefs. Arms Control Association. https://www.armscontrol.org/factsheets/Security-Council-Resolutions-on-Iran (February, 16, 2017).

Davenport, K. (2016). UN Security Council Resolutions on North Korea, Fact Sheets and Briefs, Arms Control Association.http://web.archive.org/web/20170415112133/https://www.armscontrol.org/factshee ts/UN-Security-Council-Resolutions-on-North-Korea (April 12, 2017).

European Union Council. (2012). Council Decision 2012/152/CFSP. https://www.ukpandi.com/fileadmin/uploads/ukpi/Documents/Legal_sources/16.10.12\%20Counc il\%20Decision\%20on\%20Iran.pdf (March 02, 2017)

Fifield, A. (2016). Punishing North Korea: A Rundown on Current Sanctions. The Washington Post, 22 February.

Gordon, M. \& Sanger, D. (2015). Deal Reached on Iran Nuclear Program; Limits on Fuel Would Lessen With Time. New York Times, July 14. http://www.nytimes.com/2015/07/15/world/middleeast/irannuclear-deal-is-reached-after-long-negotiations.html (April 03, 2017).

Hufbauer, P., Schott, G., Elliott, K. \& Oegg, T. (2007). Economic Sanctions Reconsidered (3rd Ed), Washington: Peterson Institute.

Joyner, D. (2011). Interpreting the Nuclear Non-Proliferation Treaty, New York: Oxford University Press.

Kaplan, F. (2005). The Real Nuclear Option: The Non-Proliferation Treaty is a Mess, We have to save it anyway.http://www.slate.com/articles/news_and_politics/war_stories/2005/05/the_real_nuclear_o ption.html (January, 17, 2017).

Kattan, A. (2013). Fact Sheet: Iran Sanctions, Centre for Arms Control and Non-Proliferation. http://armscontrolcenter.org/publications/factsheets/fact_sheet_iran_sanctions/ (April 13, 2017).

Khan, D. (2012). Nuclear Non-Proliferation Treaty, Stanford University. http://large.stanford.edu/courses/2012/ph241/khan2/ (April 17, 2017).

Lindee, S. (1994). Suffering Made Real: American Science and the Survivors at Hiroshima, Chicago: University Of Chicago Press.

Morrow, D. \& Carriere, M. (1999). The Economic Impacts of the 1998 Sanctions on India and Pakistan. The Nonproliferation Review, 6(4), 1 - 16.

Norman, L. (2012). Swift to Cut Ties With Iran Banks after EU Ban. Wall Street Journal, March 15. http://www.wsj.com/articles/SB10001424052702303863404577283532862521716 (March 02, 2017).

Norris, R. \& Kristensen, H. (2007). Pakistani Nuclear Forces. Bulletin of the Atomic Scientists, 63(3), 71- 73.

Raj, Y. (2015). Does Pakistan Have a Bigger Nuclear Arsenal than India? Hindustan Times, March 11. http://www.hindustantimes.com/world/does-pakistan-have-a-bigger-nuclear-arsenal-thanindia/story-20ZTuMDfNp9IEkZA3hx6JL.html (February 10, 2017).

Sokolski, H. (2010). Reviewing the Nuclear Nonproliferation Treaty. http://www.npolicy.org/books/Reviewing_NPT/Full_Book.pdf (January 08, 2017).

Tabrizi, A. \& Santini, R. (2012). EU Sanctions against Iran: New Wine in Old Bottles? Italian Institute for $\begin{array}{lllll}\text { International } & \text { Political } & \text { Studies } & \text { (ISPI), } & \text { Analysis }\end{array}$ http://www.ispionline.it/it/documents/Analysis_97_2012.pdf (May 16, 2017). 


\section{Journal of Social and Development Sciences (ISSN 2221-1152)}

Vol. 8, No. 2, pp. 47-55, June 2017

Toumaj, A. (2015). Deciphering the IAEA Report on Iran's PMD. Foundation for Defense of Democracies, December 4. http://www.defenddemocracy.org/media-hit/amir-toumaj-deciphering-the-iaeareport-on-irans-pmd/ (January 18, 2017).

U.S. Department of Treasury. (2017). North Korea Sanctions. https://www.treasury.gov/resourcecenter/sanctions/Programs/pages/nkorea.aspx (April 12, 2017).

Veeravalli, A. (2014). Gandhi in Political Theory: Truth, Law and Experiment, England: Ashgate Publishing Limited.

Weiss, L. (2003). Atoms for Peace. Bulletin of the Atomic Scientists, 59(6), $34-44$.

Winder, J. (2005). North Korean Bombshell Leads to Blowback. Korea Insight, 7(3), 1-4. 